
the valley and delta areas: $1856-1868$

\title{
WATER USE EFFICIENCY FOR JATROPHA IN SANDY SOIL
}

\section{F. I. Zabady ${ }^{1}$, A. A. ELMeseery ${ }^{2}$, A. A. Nassar ${ }^{3}$, and H. G. Ghanem ${ }^{4}$ ABSTRACT}

This study was conducted at Wadi El-Natron area, season (2008-2009), to evaluate the influence of three irrigation systems (Bubbler, Microsprinkler and Trickle) on Jatropha production. Also, this work includes different water management techniques, (quantities 60\%, 80\% and 100\% from $E T_{o}$ and irrigation interval of 2 and 4 days). The objective of the present work is to implement some of these intervals and water deficits in computing actual evapotranspiration of Jatropha under desert conditions, to maximize the seeds oil content production of Jatropha under different irrigation systems to save water. The results are as follows:

- Highest seeds yield production (302.40 kg/fed), was obtained under bubbler irrigation system at 100\% applied irrigation water and 2 days intervals, comparing with micro-sprinkler and trickle irrigation systems (238.48 kg/fed) and $(204.80 \mathrm{~kg} / \mathrm{fed})$, respectively.

- Maximum crude Jatropha oil content "CJO” (\%) (29.33\%) was obtained under trickle irrigation system at 60\% applied irrigation water and 4 days intervals, comparing with micro-sprinkler and bubbler systems $(24.2 \%)$ and $(23.21 \%)$, respectively.

- lowest actual evapotranspiration "ETa" for (initial, development, mid-season, and late-season) growth stages of value were (50.50, 326.37, 671.79 and 142.34) respectively and 1191mm for all-season, were obtained under trickle irrigation system at $60 \%$ applied irrigation water with 2 days intervals .

- Water use efficiency under bubbler irrigation system at $80 \%$ applied water quantity and 2 day intervals $\left(0.18 \mathrm{~kg} / \mathrm{m}^{3}\right)$ was highest than different treatments.

\footnotetext{
${ }^{1}$ Lect .Ag. Eng. Dept., Fac. of Ag., Azhar Univ., Cairo, Egypt.

${ }^{2}$ Assoc. Prof., Ag. Eng. Ag. Eng. Dept., Fac. of Ag. Azhar Univ., Cairo, Egypt.

${ }^{3}$ Assoc. Prof. Water Manag and Irri Systems-Nati .Water. Res . C ,Cairo, Egypt.

${ }^{4}$ Post grad. Stud. Agric., Dept., Fac. Ag. Azhar Univ., Cairo, Egypt.
} 


\section{INTRODUCTION}

$\mathbf{J}$ atropha curcas Linn has been the focus of research as a substitute to the scare reserves of fossil fuel due to several reasons. A part from being a non-edible oil crop, the crop exhibits growth versatility which makes it easy to be grown under a wide range of soils and climatic types. These characters open an opportunity to many countries in tropical and semi-arid regions to become biofuel producers. Beside the growth characters, their yield variability has been reported in many publications . This variability has been reported to be due to different accessions of $J$. curcas from diverse agro climatic regions (Kaushik 2007). Also, the oil content is higher, which is about $63.16 \%$ compared to linseed, soybean, and palm kernel oil, which contain only 33.33, 18.35 and 44.6\%, respectively (Gunstone, 2004). The crude Jatropha oil (CJO )content has been related to harvesting time. Jatropha needs around 90 days to mature from the day after fruit bloom. (Jupikely et al. 2010 ). The 90 days as an indication of harvest time by previous researches was due to a claim that black dry fruit results in high CJO. In contrast to the recommended harvesting time, Wanita and Hartono (2006) reported that high CJO in Jatropha fruits was from fully yellow color fruits or when bunch age is 45 days. The CJO was reported to be around 36.83 and $63.06 \%$ in seeds and kernels respectively.It is important to note that not all oils in the kernels can be extracted during extraction .Oil extraction was reported to range from $70-80 \%$ (Achten et al. 2008) . The yield of extracted oil was $28.69,58.39,30.17$ and $22.15 \mathrm{~kg} \mathrm{ha}^{-1}$ at $125 \%, 100 \%, 75 \%$ and $50 \%$ of potential evapotranspiration, respectively at micro-sprinkler system. The lowest values of total lipid (oil) (25\% and 24.5\% of Jatropha seeds) were recorded with Jatropha trees that were irrigated by $125 \%$ and $50 \%$ of ETp, respectively. On the other hand, the treatment that was irrigated by $100 \%$ of ETp (control) recorded the highest value of total oil in the seeds $(29.93 \%)$. There are no significant difference among the values of oil characteristics due to different water stress ratios. The highest characteristics of Jatropha seed oil were recorded with $100 \%$ of ETp. In addition; water stress had no significant effect on the fatty acid composition of Jatropha seed oil( Kheira and Atta, 2009). The crop coefficient of both olive and fig trees grown in El-Sheikh Zewid, North 
Sinai (الثيخ زويد،شمال سيناء), and Egypt increased with the increase of irrigation water amounts, adding organic manure and trees age. Meanwhile Kc values tend to decrease by using black plastic mulch (Seidhom, 2001).

\section{MATERIALS AND METHODS}

\subsection{Experimental treatments:}

The main experiments were carried out during the season of (2008-2009) at Wadi EL Natrown(وادى النطرون)On-Farm Irrigation Department Research Station, Water Management and Irrigation Systems Research Institute, El-Behera governorate Egypt(محافظة البحيره), to study Jatropha irrigation scheduling. The Wadi El-Natrun Research Station lies at $30^{\circ}$ $25^{\prime} 0 \mathrm{~N}$ latitude, $30^{\circ} 13^{\prime} 0 \mathrm{E}$ longitude, while the altitude is $36 \mathrm{~m}$ above the sea level .The field study was carried out in split - split plot design with two replicates. The distance between the trees was 5 x $5(\mathrm{~m})$. The experiment was started in march (2008-2009) after 3 years from Jatropha planted at 168 tree/fed. Mean height of tree at starting was $155(\mathrm{~cm})$.

Mean diameter of stok at distance $40(\mathrm{~cm})$ from soil was $8(\mathrm{~cm})$ and the mean area of tree shade at $12 \mathrm{pm}$ was $1.76\left(\mathrm{~m}^{2}\right)$. The sub-main plots were irrigated by three applied water quantities (Q)(60\%, 80\% and $100 \%$ ) obtained from the product of the reference evapotranspiration (ETo) calculated by using Penman-Montieth equation multiplied by crop coefficient for every stage. The sub sub-main plots were two intervals as 2 and 4 days as water distribution under three irrigation systems, (Bubbler, Micro-sprinkler and Trickle).

The reference evapotranspiration (ETo) was calculated by using "CropWat 4 windows" (version 3.4), Smith (1991) Software Program, according to the monthly mean of 30 years. Moreover, Table (4) illustrates the growth periods (days) of the Jatropha crop, i.e., establishment or initial stage, vegetative or development stage, flowering or mid-season and yield formation or late-season. 
Table (4): Period length (days), crop coefficient $\left(\mathrm{Kc}_{\mathrm{FAO}}\right)$ and reference evapotranspiration (ETo) of Jatropha growth stages and total season.

\begin{tabular}{|c|c|c|c|c|c|}
\hline Stages & Initial & Develop & Mid & Late & Total \\
\hline Period length (day) & 25 & 40 & 65 & 50 & 180 \\
Kc $_{\mathrm{FAO}}$ & 0.35 & 1.15 & 1.15 & 0.35 & ------ \\
ETo $(\mathbf{m m})$ & 217 & 384.8 & 778.6 & 579.3 & 1959.7 \\
\hline
\end{tabular}

\subsection{Soil characteristics:}

Some physical properties of soil were measured in the Laboratory of Water Requirements and Meteorology unit associated with the Physical and Chemical Department in Agricultural Research Center, Ministry of Agriculturel, El-Doky, Cairo, Egypt as represented in Table (1).

Table (1):some physical characteristics of the soil under study.

\begin{tabular}{|c|c|c|c|c|c|c|c|c|c|c|c|c|}
\hline \multirow{2}{*}{$\begin{array}{c}\text { Soil } \\
\text { depth } \\
(\mathrm{cm})\end{array}$} & \multicolumn{4}{|c|}{ Particle size distribution, $\%$} & \multirow{2}{*}{$\begin{array}{c}\text { Textural } \\
\text { class }\end{array}$} & \multirow[b]{2}{*}{$\begin{array}{c}\mathrm{CaCO}_{3} \\
\%\end{array}$} & \multirow[b]{2}{*}{$\begin{array}{l}\text { P.D. } \\
\mathrm{g} / \mathrm{cm}^{3}\end{array}$} & \multirow[b]{2}{*}{$\begin{array}{l}\text { B.D. } \\
\mathrm{g} / \mathrm{cm}^{3}\end{array}$} & \multirow{2}{*}{$\begin{array}{l}\text { H.C. } \\
\mathrm{cm} / \mathrm{h}\end{array}$} & \multirow{2}{*}{$\begin{array}{c}\text { F.C. } \\
\%\end{array}$} & \multirow{2}{*}{$\begin{array}{c}\text { W.P. } \\
\%\end{array}$} & \multirow{2}{*}{$\begin{array}{c}\text { A.W } \\
\%\end{array}$} \\
\hline & $\begin{array}{c}\mathrm{C} . \\
\text { sand }\end{array}$ & $\begin{array}{c}\text { M. } \\
\text { sand }\end{array}$ & $\begin{array}{c}\text { F. } \\
\text { sand }\end{array}$ & $\begin{array}{l}\text { V.F. } \\
\text { sand }\end{array}$ & & & & & & & & \\
\hline $0-30$ & 2.10 & 87.52 & 8.13 & 2.25 & S. & 1.61 & 2.58 & 1.58 & 8.27 & 9.14 & 2.38 & 6.76 \\
\hline $30-60$ & 5.59 & 79.84 & 9.91 & 4.66 & $\mathrm{~S}$. & 1.84 & 2.63 & 1.55 & 4.80 & 9.67 & 2.42 & 7.25 \\
\hline
\end{tabular}

Coarse (C.), medium (M.), fine (F.) and very fine (V.F.), sand. S. = sand, P.D. = particle density $\left(\mathrm{g} / \mathrm{cm}^{3}\right)$, B.D. $=$ Bulk density $\left(\mathrm{g} / \mathrm{cm}^{3}\right)$, H.C. $=$ Hydraulic Conductivity $(\mathrm{cm} / \mathrm{h})$, F.C. =Field capacity $(0.1 \mathrm{~atm}) \$.$% ,$ W.P. =Permanent Wilting Percentage $(15 \mathrm{~atm}) \%$ and A.W. =Available soil water $\%$.

The amounts of irrigation water were calculated using the following equation:

$$
\text { I.W. }=\underline{\text { ETo } * K C * T i * A * L i} \quad \mathbf{m}^{3}
$$

$\eta$

\section{Where:}

I.W : amount of irrigation water, $\mathrm{m}^{3}$ per irr. 
ETo : potential evapotranspiration, $\mathrm{mm} /$ day.

Kc : crop coefficient from FAO.

Ti : irrigation frequency in days (2and4 days).

A : the mean area of tree shade, $\mathrm{m}^{2}$.

$\boldsymbol{\eta}$ : irrigation systems efficiency $(\%)$

Li : leaching requirements $(10 \%)$

\subsection{Actual evapotranspiration "ETa" (mm/day) determination technique:}

To determine water consumption of Jatropha, soil samples were collected from each treatment at $0-30 \mathrm{~cm}$ and $30-60 \mathrm{~cm}$ soil depths periodically before and after each irrigation. The crop water consumptive use was calculated by the following equation:

$$
\mathrm{ETa}=\underline{\left(M_{2} \%-M_{1} \%\right) \times d_{\mathrm{b}} \times \mathbf{D}} \mathbf{m m}
$$

Where:

\section{0}

ETa : actual evapotranspiration, $\mathrm{mm}$.

$\mathrm{M}_{2}$ : moisture content after irrigation $\%$.

$\mathrm{M}_{1}$ : moisture content before irrigation $\%$.

$d_{\mathrm{b}} \quad$ : specific density of soil .

D : mean depth of root $(600 \mathrm{~mm})$.

\subsection{Water use efficiency"WUE" $\left(\mathrm{kg} / \mathrm{m}^{3}\right)$ determination:}

Water use efficiency was calculated by dividing the crop yield by the amount of seasonal water consumptive use.

$$
\mathrm{WUE}=\mathrm{Y} / \mathrm{CU}
$$

Where:

Y : dry yield or marketable dry matter, $\mathrm{kg}$.

CU: seasonal water consumptive use $\left(\mathrm{m}^{3}\right)$.

\subsection{Water application efficiency "WAE" $(\%)$ :}

\section{Where:}

$$
\mathrm{WAE}=\mathrm{W}_{\mathrm{S}} / \mathbf{I W}
$$

WAE: water application efficiency.

Ws : water storage in effective root zone.

IW : amount of irrigation water, $\mathrm{m}^{3}$ per irr. 


\subsection{Statistical analysis:}

Statistica software program \&SPSS software was used according to SPSS Inc. according that Snedecor G. W. and Cochran W.G. (1982).

\section{RESULTS AND DISCUSSION}

\subsection{Growth parameters:}

\subsubsection{Height of plant " $H$ " (\%):}

Data in Figure (1) shows that the height of plant " $H$ " $(\mathrm{m})$ increases with the increase of applied water quantities and decreasing the intervals for bubbler, micro-sprinkler and trickle irrigation systems. The maximum mean value of height increases percentage was $33.5 \%$ at $100 \%$ applied water quantity and 2 days intervals for bubbler irrigation system. Meanwhile the minimum mean value of height increase percentage was $13.5 \%$ at $60 \%$ applied water quantity and 4 days intervals for trickle irrigation system.

The data revealed that the values of height percentage were no significant affected by changing intervals between 2 and 4 days and difference between applied water quantities $100 \%$ and $80 \%$ for all conditions under study. Meanwhile there was significantly for applied water quantity $60 \%$.

\subsubsection{Diameter of plant " $D$ " $(\%)$}

Data in Figure (1) shows that the Diameter of plant increases with the increase of applied water quantities and decreased intervals for bubbler, micro-sprinkler and trickle irrigation systems. The maximum mean value of diameter increase percentage was $43.8(\%)$ at $100 \%$ applied water quantity and 2 days intervals for bubbler irrigation system. Meanwhile the minimum mean value increase percentage was $16.7(\%)$ at $60 \%$ applied water quantity and 4 days intervals for trickle irrigation system.

\subsubsection{The mean area of tree shade" $A$ " $(\%)$}

Data in Figure (1) shows that the mean area of tree shade increases with the increase of applied water quantities and decreasing the intervals for bubbler, micro-sprinkler and trickle irrigation systems. The maximum mean value of area increase percentage was $32.8(\%)$ at $100 \%$ applied water quantity and 2 day intervals for bubbler irrigation system. Meanwhile the minimum mean value increase percentage was $15(\%)$ at $60 \%$ applied water quantity and 4 days intervals for trickle irrigation system. 


\subsection{Crude oil content percentage "CJO" (\%):}

Data in Figure (2) shows that the crude oil content percentage "CJO" (\%) increases with the decrease of applied water quantities and increased intervals for bubbler, micro-sprinkler and trickle irrigation systems. The maximum mean value of "CJO" was $29.33 \%$ at $60 \%$ applied water quantity and 4 days intervals for trickle irrigation system. Meanwhile the minimum mean value was $16.21 \%$ at $100 \%$ applied water quantity and 2 days intervals for bubbler irrigation system.

\subsection{Jatropha seeds yield" Sy" (kg/fed):}

Data in Figure (2) shows that the seeds yield "Sy" kg/fed increases with the increase of applied water quantities and decreased intervals for bubbler, micro-sprinkler and trickle irrigation systems. The maximum mean value of "Sy" was $302.40 \mathrm{~kg} / \mathrm{fed}$ at $100 \%$ applied irrigation water and 2 days intervals for bubbler irrigation system. Meanwhile the minimum mean value was $102.44 \mathrm{~kg} / \mathrm{fed}$ at $60 \%$ applied irrigation water and 4 days intervals for trickle irrigation system.

The data revealed that the values of "Sy" $\mathrm{kg} / \mathrm{fed}$ were no significant affected by changing intervals between 2 and 4 days and difference between applied water quantities $100 \%$ and $80 \%$ for all conditions under study. Meanwhile there was significantly for applied water quantity $60 \%$. So, it is recommended to use applied water quantaities, (80\%) to save $20 \%$ water.

\subsection{Water use efficiency "WUE" $\mathrm{kg} / \mathrm{m}^{3}$ :}

Data in Figure (2) shows that the maximum value of "WUE" was 0.18 $\mathrm{kg} / \mathrm{m}^{3}$, at $80 \%$ applied irrigation water and 2 days intervals for bubbler irrigation system. Meanwhile the minimum value was $0.04 \mathrm{~kg} / \mathrm{m}^{3}$, at $60 \%$ applied irrigation water and 4 days intervals for trickle irrigation system.

\subsection{Actual evapotranspiration "ETa" $(\mathrm{mm})$ for all growth stages:}

Data in Figure (3) shows that the maximum mean values of actual evapotranspiration "Eta" for (initial, development, mid-season , and lateseason) growth stages were 87.41, 469.28, 960.29, and $243.09 \mathrm{~mm}$ respectively, and whole season $1760.07 \mathrm{~mm}$ at $100 \%$ applied irrigation water and 4 days intervals for bubbler irrigation system. Meanwhile the minimum mean values were 50.50, 326.37, 671.79, 142.34 and $1191 \mathrm{~mm}$ respectively, at $60 \%$ applied irrigation water and 2 days intervals for trickle irrigation. 


\subsection{Water application efficiency "WAE" $(\%)$ :}

Data in Figure (4) shows that the maximum of water application efficiency "WAE" was $94.27 \%$ at $60 \%$ applied irrigation water and 2 day intervals for trickle irrigation system. Meanwhile the minimum was $68.2 \%$ at $100 \%$ applied irrigation water and 4 days intervals for bubbler irrigation system.

2 Days
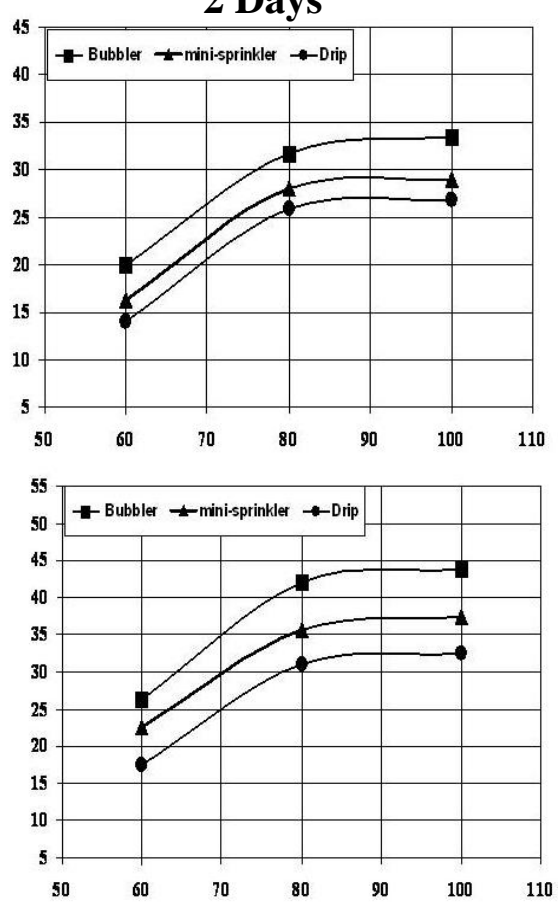

हैं

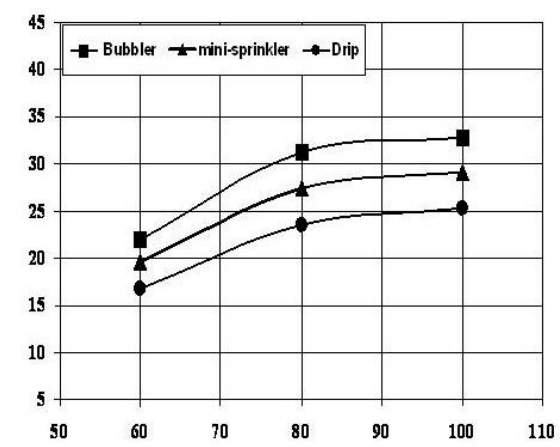

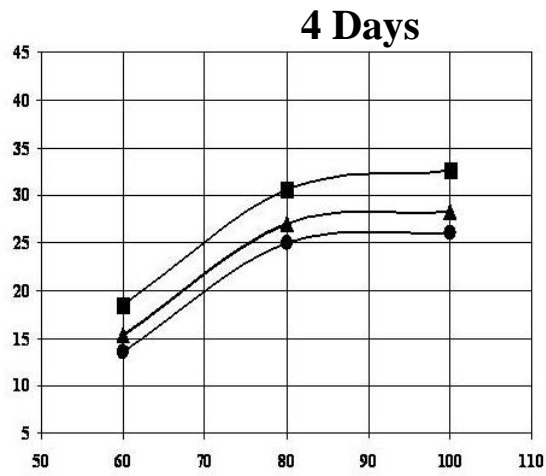
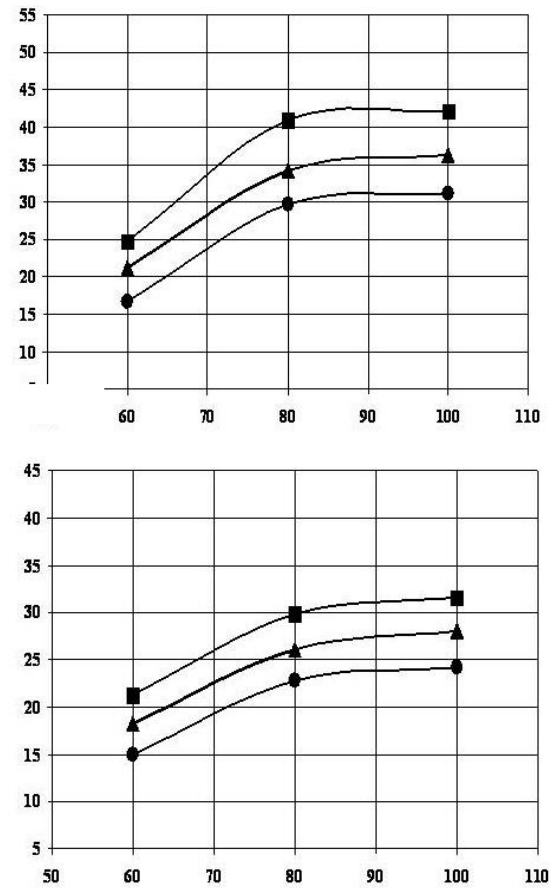

Applied irrigation water "IW" (\%)

Fig.(1): Increased Plant height "H"(\%), plant diameter "D"(\%) and plant area " $A "(\%)$ at applied irrigation water "IW" (\%) and different intervals "Int." (Days) for bubbler, micro- sprinkler and trickle irrigation systems on Jatropha. 

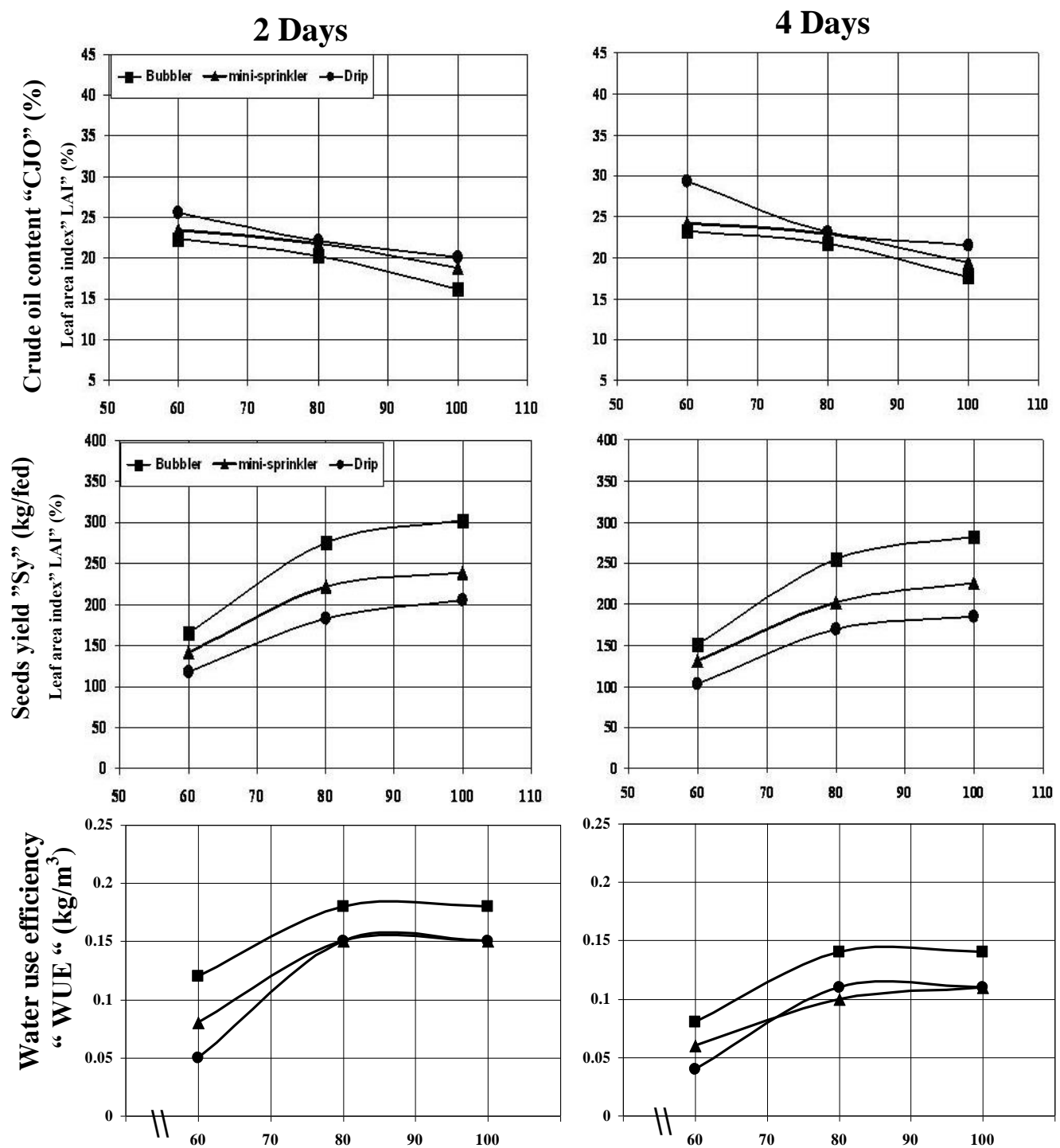

Applied irrigation water "IW"

Fig.(2): crude oil content "CJO" (\%), Seeds yield "Sy" (kg/fed) and water use efficency $\left(\mathrm{kg} / \mathrm{m}^{3}\right)$ at applied irrigation water "IW" (\%) and different intervals "Int." (Days) for bubbler, micro- sprinkler and trickle irrigation systems on Jatropha. 
2 Days

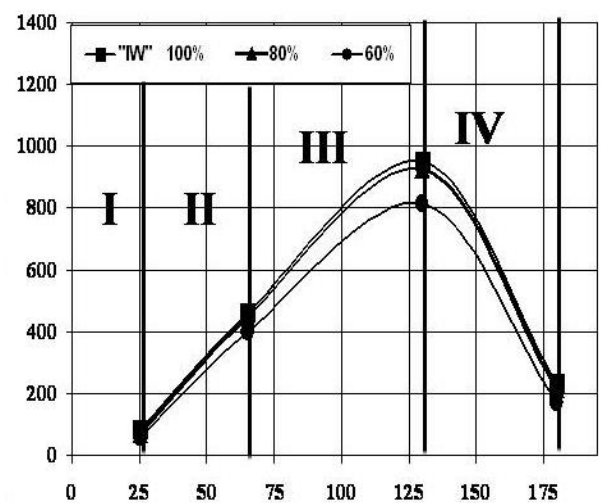

E
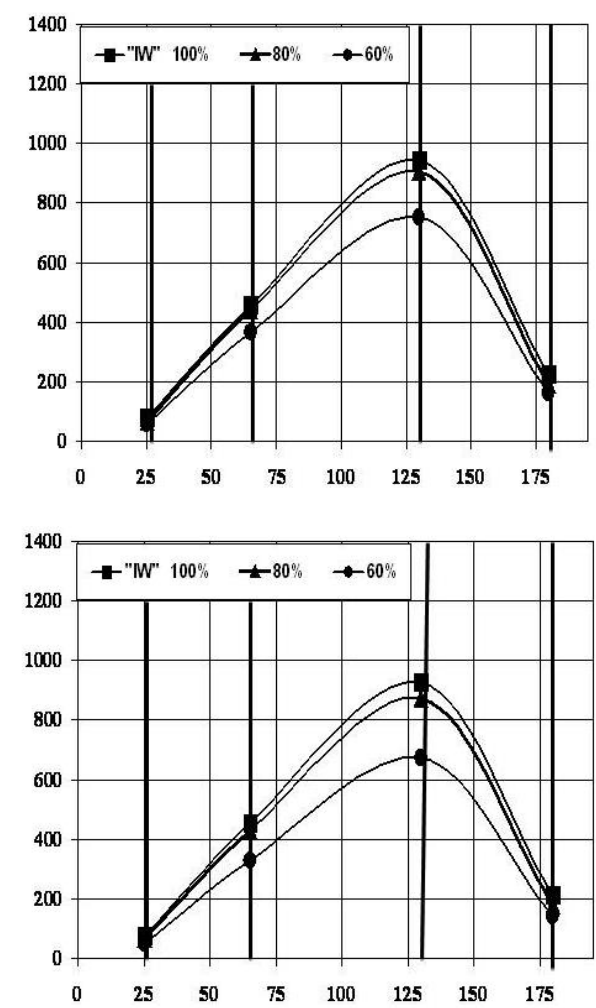

4 Days
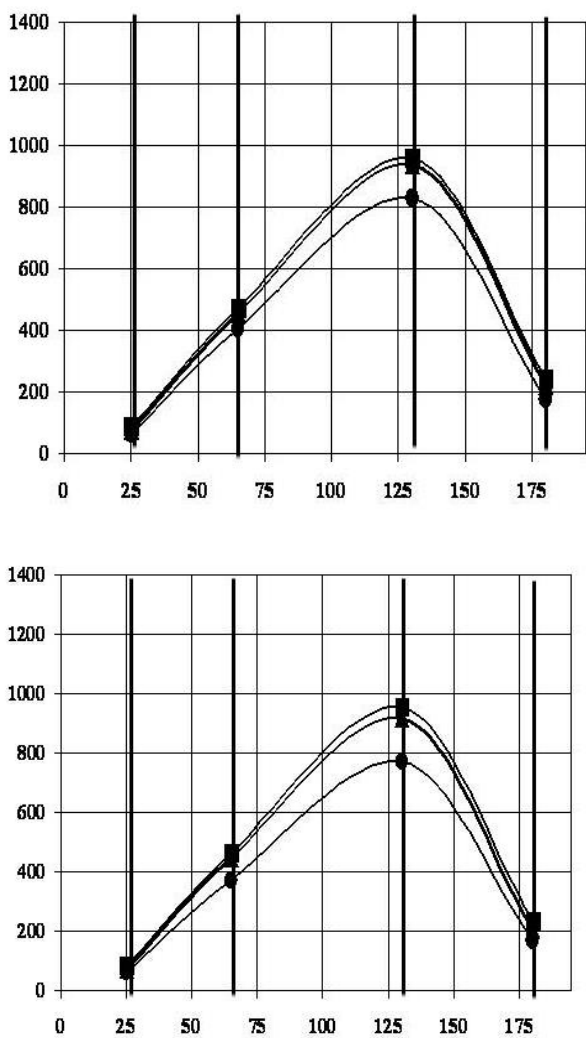

卷

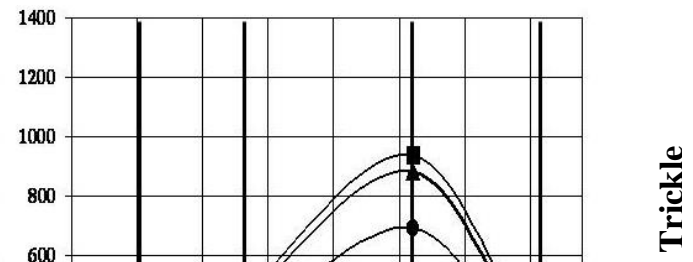

Growth stages (initial "I"- develop. "II"- mid "III"- late."IV") /days.

Fig.(3): Actual evapotranspiration "Eta" (mm) for all growth stages at different applied irrigation water "IW" (\%) and different intervals "Int." (Days) for bubbler, micro-sprinkler and trickle irrigation systems on Jatropha.

The $17^{\text {th }}$. Annual Conference of the Misr Society of Ag. Eng., 28 October, $2010 \quad-1865-$ 
4 Days

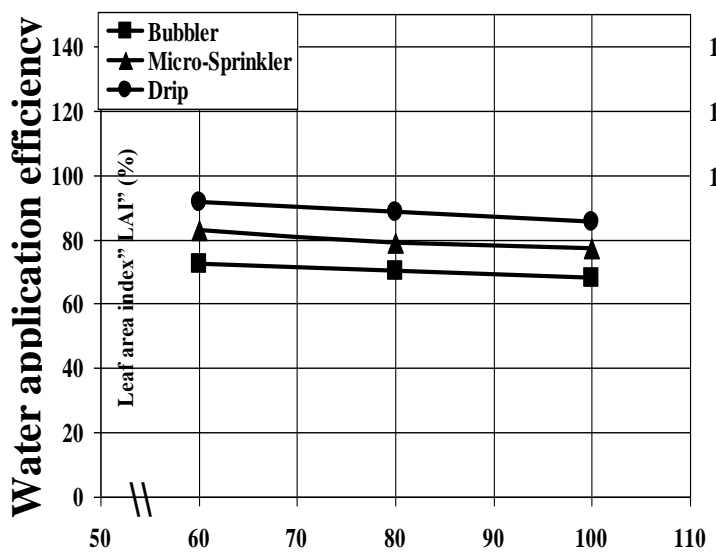

2 Days

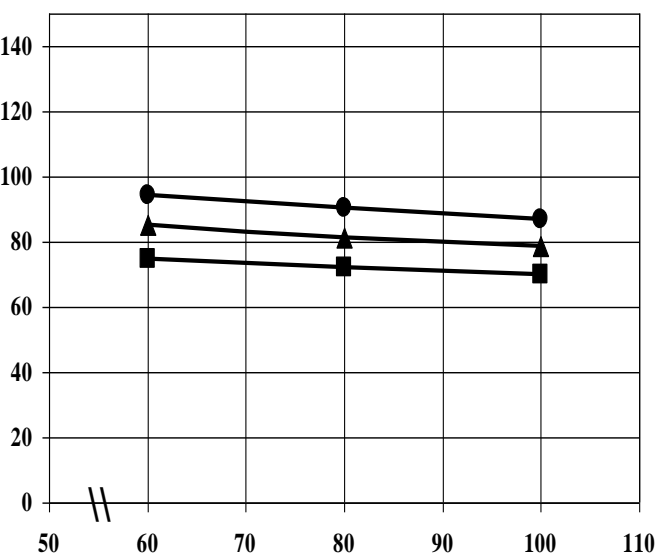

Applied irrigation water"IW" (\%)

Fig.(4): Water application efficiency "WAE"(\%) at applied irrigation water "IW" (\%) and different intervals "Int." (Days) for bubbler, micro- sprinkler and trickle irrigation systems on Jatropha.

\section{CONCLUSIONS}

\section{Results could be summarized as follows:}

1- The values of "Sy" " (kg/fed), "H" (\%) and "CJO" (\%)were no significant affected by changing intervals between 2 and 4 days and difference between applied water quantities $100 \%$ and $80 \%$ for all conditions under study. Meanwhile there were significantly for applied water quantity $60 \%$.

2- The maximum mean value(\%) of "Sy" and "H" were $(302.40 \mathrm{~kg} / \mathrm{fed}$ and $33.5 \%$ ) respectively, at $100 \%$ applied irrigation water and 2 day intervals for bubbler irrigation. Meanwhile the minimum mean values were $(102.44 \mathrm{~kg} / \mathrm{fed}$ and $13.5 \%)$ at $60 \%$ applied irrigation water and 4 day intervals for trickle irrigation system.

3- The maximum mean seasonal value of "ETa" was 1760.07 $\mathrm{mm} / \mathrm{season}$, at $100 \%$ applied irrigation water and 4 day intervals for bubbler irrigation system. Meanwhile the minimum mean value was $1191 \mathrm{~mm} / \mathrm{season}$ at $60 \%$ applied irrigation water and 2 day intervals for trickle irrigation system. 
4- The maximum mean value of "WUE" was $0.18 \mathrm{~kg} / \mathrm{m}^{3}$, at $80 \%$ applied irrigation water and 2 days intervals for bubbler irrigation system. Meanwhile the minimum mean value was $0.04 \mathrm{~kg} / \mathrm{m}^{3}$, at $60 \%$ applied irrigation water and 4 day intervals for trickle irrigation.

\section{REFERENCES}

Achten, W. M. J.; L. Vercot; Y. J. Franken; E. Mathijs; V. P. Singh; A. Aerts and B. Muys (2008). Jatropha bio-diesel production and use. Biomass and Bioenergy. 32: 1063-1084.

Abou Kheira, A. A. and N. M. Atta (2009). Response of Jatropha curcas L. to water deficits: Yield, water uses efficiency and oilseed characteristics J Plant Physiology. Biomass and Bioenergy 33(10): 1343-1350.

Gunstone, F.D. (2004). Rapeseed and canola oil: Production, processing, properties and uses. London: Blackwell Pub Ltd.4 (2):125-138.

Jupikely ,j.s . ;A.H.Tambunan.;E.Hambali.; Sutrisno.;M.Surahman (2010). Extracted Oil yield and biomass changes during on-tree maturation, ripening and senescence of Jatropha curcas linn fruits. European J Sc Res ISSN 1450-216X .44 (4), :.602-609.

Kaushik, N. (2007). Quality planting material and seed standard in Jatropha curcas. In: Singh, B., Sawaminthan, R., Ponraj, V. editors. Proc Biodiesel Conf Towards Energy Independence - Focun on Jatropha. Hyderabad, India, Jun 9 - 10. New Delhi: Rashtrapati Bahwan :88 - 91 .

Snedecor G. W. and Cochran W.G. (1982). Statistical methods. 7th.ed. IOWA, State Univ. Press ,Ames., U.S.A.: 145-166.

Smith N. (1991). CROPWAT model for ETO calculation using PenmanMontieth method, FAO, Rome, Italy: 112-140.

Seidhom, S. H. (2001). Water use efficiency and water economy of some crops as affected by soil heat at Sinai. Ph. D. Thesis, Fac. of Agric., Zagazig Univ., Egypt..: 44 - 48.

Wanita, Y. P. and J. Hartono (2006). P (The effect of fruit maturity stage on oil content of Jatropha curcas L.). Paper presented at Lokakarya II: Status Teknologi Tanaman Jarak Pagar. Pusat Penelitian dan Pengembangan Perkebunan. 2(6): 263- 281. 


\section{الملخص العزبي \\ "كفاءة الأستهلاك المائى للجتروفا فى الأراضى الرملية "}

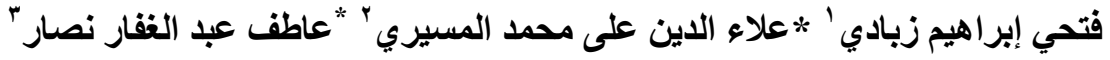

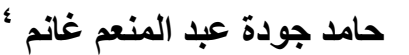

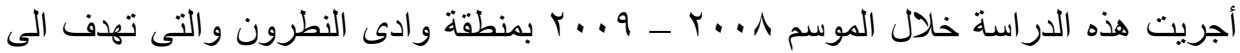
تطبيق ثلاثة أنظمة رى وهى (النافورى والرش و التنقيط) وتحديد أيها أنسب فى انتاج بذور

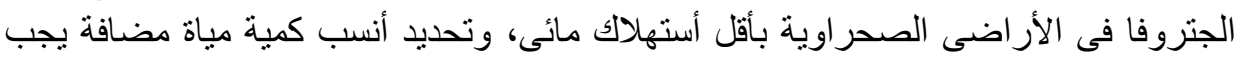

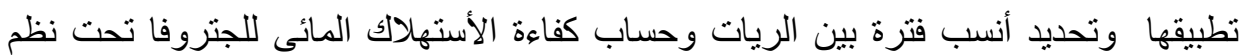

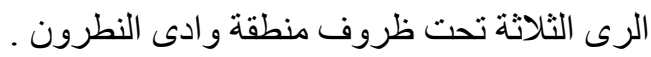

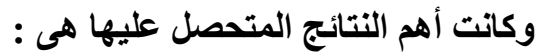

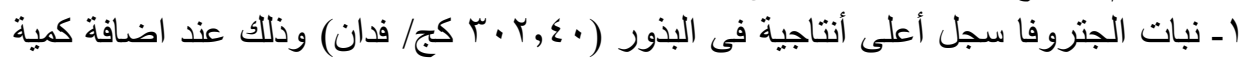

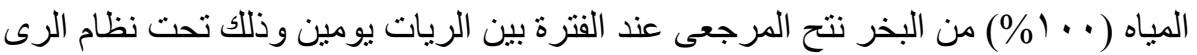

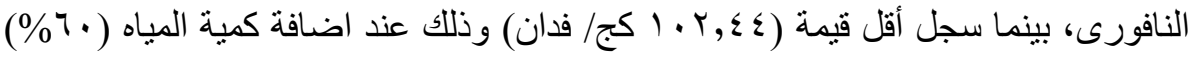

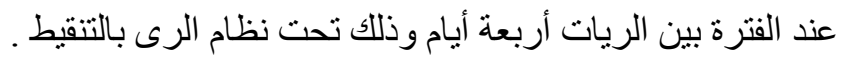

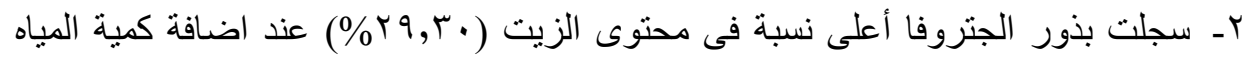

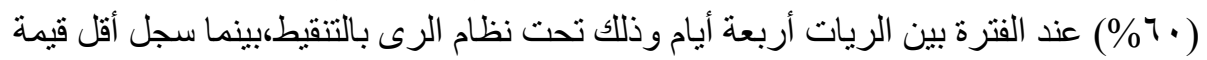

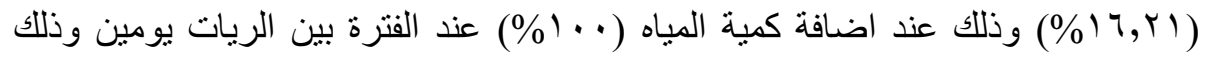

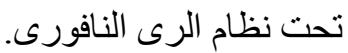

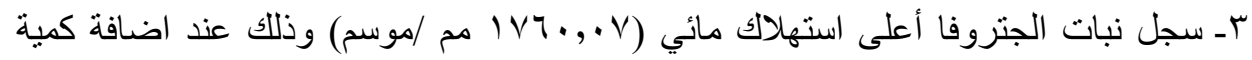
المياه ( . ( (\%) عند الفترة بين الريات أربعة أبام،وذللك تحت نظام الرى النافورى بينما

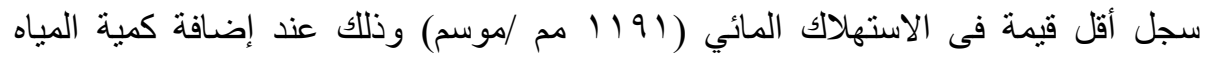

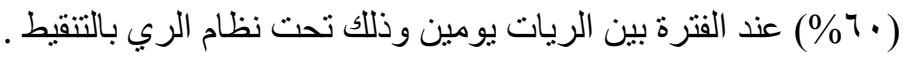

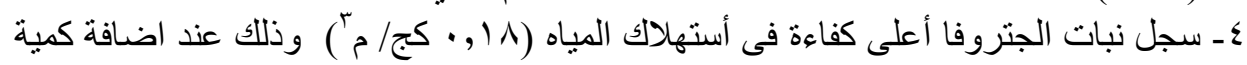

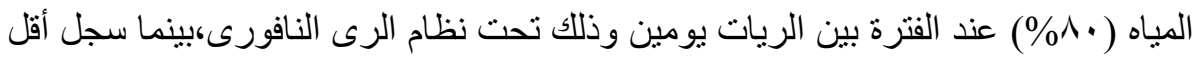

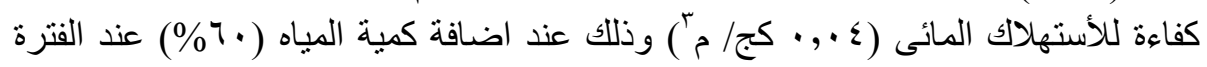

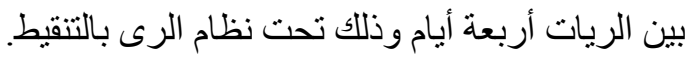

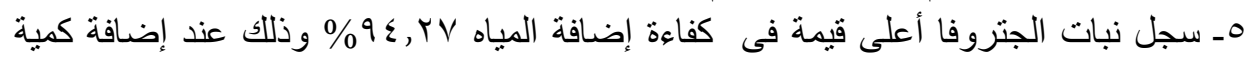

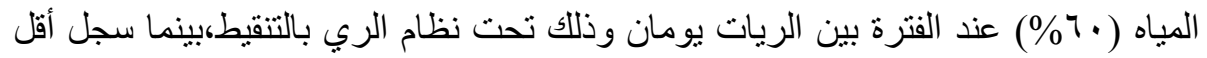

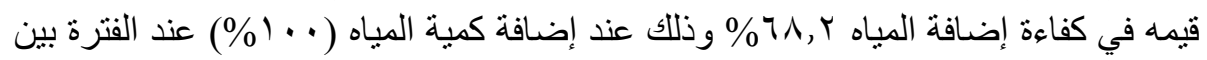
الريات أربعة أيام وذلك تحت نظام إفه الرياه بام النافورى .

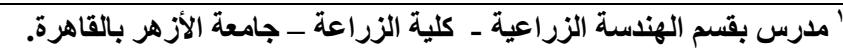

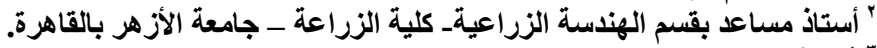

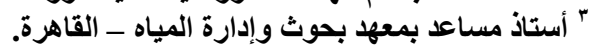

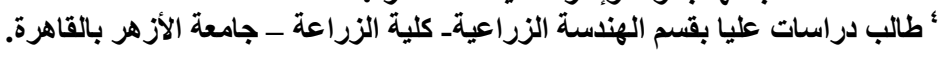

